American Journal of Pharmacology and Toxicology 4 (3):107-117, 2009

ISSN 1557-4962

(C) 2009 Science Publications

\title{
Camel's Milk Protects Against Cadmium Chloride Induced Toxicity in White Albino Rats
}

\author{
${ }^{1}$ Fahaid Al-Hashem, ${ }^{1}$ Mohammad Dallak, ${ }^{2}$ Nabil Bashir, ${ }^{3}$ Mohammad Abbas, \\ ${ }^{3}$ Riyadh Elessa, ${ }^{4}$ Mohammad Khalil and ${ }^{5}$ Mahmoud Al-Khateeb \\ ${ }^{1}$ Department of Physiology, College of Medicine, King Khalid University, Abha 64121, Saudi Arabia \\ ${ }^{2}$ Department of Biochemistry, Faculty of Medicine, \\ Jordan University of Science and Technology, Irbid 21110, Jordan \\ ${ }^{3}$ Department of Biochemistry, College of Medicine, King Khalid University, Abha 64121, Saudi Arabia \\ ${ }^{4}$ Division of Physiology, Department of Basic Medical Sciences, \\ Faculty of Medicine, King Fahid Medical City, Riyadh 11393, Saudi Arabia \\ ${ }^{5}$ Department of physiology, College of Medicine, King Khalid University, Abha 64121, Saudi Arabia
}

\begin{abstract}
Problem statement: Cadmium is one of the most dangerous occupational and environmental toxins. It is found in drinking water, atmospheric air and even in food. Cadmium is reported to be very toxic to biological systems. Until now in treating intoxication with this metal, chelating Compounds have been used, burdened with numerous undesirable symptoms. For this reason, many researches are carried out in many countries to find natural-made compounds that help in the protection against cadmium induced toxicity with fewer or no side effects. This study was conducted to demonstrate the effect of daily oral Camel's milk administration against Cadmium chloride induced toxicity in white albino rats. Approach: White albino rats of both sexes (230-250 g) were housed in standard metal cages (6 rats/cage). The experimental rats (6 in each group) distributed into two experimental groups with a shared control group received only normal saline orally (Group 1). In experimental first group a daily dose $\left(10 \mathrm{mg} \mathrm{kg}^{1}\right.$ body weight $)$ of cadmium chloride was orally administrated to the rats for 21 days and named Cadmium chloride treated rats. In experimental second group, the same concentrations of cadmium chloride was dissolved in $2 \mathrm{~mL}$ of early morning fresh Camel's milk and the whole solution was administered into the experimental rats for 21 days and named Camel's milk cadmium chloride treated group. Water and food were provided ad libitum. Results: The data indicated that, in experimental Cadmium chloride treated rats, serum albumin, calcium and blood hemoglobin were decreased compared with control group received normal saline only. Moreover, Camel's milk administration with cadmium chloride showed a significant improvement of albumin, hemoglobin and calcium levels in the serum of the rats compared with cadmium chloride treated rats. Serum iron, sodium, chloride and urea levels were significantly increased in cadmium chloride treated rats compared with control group, while the addition of camel's milk to cadmium chloride decreased the high levels of these serum parameters in the treated rats. The enzyme activities of serum Alanine Aminotransferase (ALT), Aspartate Aminotransferase (AST) and serum Alkaline Phaospatase (ALP) were significantly increased by orally administration of cadmium chloride compared with control group, while adding Camel's milk to cadmium chloride decreased the high levels of these enzymes comparing with the cadmium chloride treated rats. Cadmium chloride administration resulted in a high concentration of lipid peroxidation markers; TBARS and Hydroperoxides in comparison to control group, adding camel's milk to the cadmium chloride restored the levels of these markers to their normal levels in comparing to Cadmium chloride treated rats. Also treatment with cadmium chloride alone caused a significant decrease in both the enzymatic and nonenzymatic markers of oxidative stress (superoxide dismutase and catalase) and reduced glutathione, respectively in the liver tissues of treated rats, while the administration of camel's milk with cadmium chloride increased and restored their levels to near normal in comparing with cadmium chloride treated rats. These results demonstrated that camel's milk had a protective effect against the toxicity induced by cadmium chloride. Conclusion: the above results indicated a protective effect of camel's milk oral administration against cadmium induced toxicity in white albino rats.
\end{abstract}

Key words: Camel, milk, cadmium chloride and toxicity

Corresponding Author: Fahaid Al-hashem, Department of Physiology, College of Medicine, King Khalid University, Abha 64121, Saudi Arabia Tel: +962500142929 Fax: +96672289300 


\section{INTRODUCTION}

It is now well realized that environmental problems have increased exponentially in recent decades mainly because of rapid growth in human population and increased demand for several household materials. The toxic chemicals discharged into air, water and soil get into food chain from the environment. By entering into the biological system they disturb the biochemical processes leading to health abnormalities. Trace elements were known to have a variety of important biological functions and in many instances; they may have adverse effects on biological system ${ }^{[1-3]}$.

Cadmium exists in the air and water pollutants. In this respect, cadmium is a heavy metal of wide occupational and environmental contamination and present in trace levels in seawater and in a broad range of animal and plant species. Relatively large quantities of cadmium are found in commercial phosphate fertilizer, thus the increases in soil and plant cadmium contents may lead to increases in dietary cadmium. Also, cadmium poses a potential environmental hazard due to increased in its industrial use ${ }^{[4-7]}$.

Cadmium toxic effects on biological systems have been extensively reported ${ }^{[8]}$. Free radicals are evolved at the early stages of cadmium intoxication ${ }^{[9,10]}$. The inhalation or absorption of Cadmium from various sources may lead to its accumulation in the human body $^{[11-13]}$.

It has been reported that administration of cadmium via different routes causes increased lipid peroxidation in membranes of erythrocytes and tissues such as the liver, kidney, brain and testes where MDA is used as an indicator of oxidative damage ${ }^{[14]}$. Intake of cadmium results in consumption of glutathione and protein binding sulfyhydral groups and subsequently the levels of free radicals such as hydrogen peroxide, hydroxide and superoxide are increased. Increased lipid peroxidation results in changes in intracellular stability, DNA damage and apoptosis ${ }^{[15]}$. Bagchi et al. ${ }^{[16]}$ reported that the levels of glutathione peroxidase (GSH$\mathrm{Px})$ were increased whereas a reduction was observed in the activity of glutathione reductase in experimental cadmium-induced toxicity.

The high dietary levels of cadmium results in suppressed feed intake, reduction in bone mineralization and anemia ${ }^{[5]}$. The biochemical alteration occur prior to morphological changes in the organs and changes in certain enzyme levels in the extracellular fluids may reflect the extent of cadmium induced damage in target organs ${ }^{[17]}$.

For the general population that is mainly exposed by oral and inhalation routes, Kidneys (mainly renal cortex) and liver are considered to be the most susceptible organs in the case of exposure to cadmium $^{[18-20]}$. The soluble salts of Cadmium accumulate in the organism and affect toxically not only the liver and kidneys, but also the brain, lungs, testicles, central nervous system and other tissues ${ }^{[21]}$.

The damaging effect of cadmium on the liver is manifested by an increase of Aspartate Aminotransferase (AST) and of the most specific marker of liver cell damage Alanine Aminotransferase (ALT). Sauer et al. ${ }^{[22]}$ and Blasco and Puppo ${ }^{[23]}$ observed an increase of the activity of these enzymes as a result of cadmium activity. Sherlock and Dooley ${ }^{[24]}$ and Lee et al. ${ }^{[25]}$ reported that Lactate Dehydrogenase (LDH) is another index of hepatotoxicity, although the plasma LDH level is relatively insensitive when exposed to cadmium. Cadmium hepatotoxicity is probably affected in two ways: On the one hand by the occurrence of inflammatory state, on the other hand-by direct toxic action of cadmium on liver cells. So far in treating cadmium intoxications, chelating compounds have been used, e.g., calcium disodium versenate, dimercaprol and mesomercaptosuccinic acid ${ }^{[26,27]}$.

It is known that chronic exposure to cadmium can induce severe nephropathy in humans ${ }^{[28]}$ and animals ${ }^{[29,30]}$. This nephrotoxic causes reabsorptive and secretory dysfunction of the renal tubule. Several mechanisms have been proposed to explain the toxic effect of Cadmium on renal cells. Cadmium may cause nephrotoxicity by generating free radicals ${ }^{[31]}$ and by inducing necrosis and apoptosis ${ }^{[32]}$.

Camel's milk is different from other ruminant milk; having low cholesterol, low sugar, high minerals (sodium, potassium, iron, copper, zinc and magnesium), high vitamin $\mathrm{C}, \mathrm{B} 2, \mathrm{~A}$ and $\mathrm{E}$, low protein and high concentrations of insulin ${ }^{[33]}$. It has no allergic properties and it can be consumed by lactase deficient persons and those with week immune systems.

The milk is considered to have medicinal properties. In Sahara, fresh butter is often used as a base for medicines. The products developed also include cosmetics or pharmaceuticals. A series of metabolic and autoimmune diseases are successfully being treated with camel's milk. In India, camel's milk is used therapeutically against dropsy, jaundice, problems of the spleen, tuberculosis, asthma, anemia, piles and diabetes ${ }^{[34]}$. Beneficial role of raw camel's milk in chronic pulmonary tuberculosis patients has been observed $^{[35]}$. In repeated trials, it was observed that there was 30-35\% reduction in daily doses of insulin in patients of type 1 diabetes receiving raw camel's milk $^{[36]}$. It is mentioned in Islam online that Camel's 
milk and urine have medical effects, so Islam encourages and permits the drinking of camel milk and camel urine is permitted in case of necessary medical treatment.

The unique composition of camel milk has been proved to fortify the immunity system, where it has a heavy chain of amino acids which makes the camel's milk so unique. Such immunity components have proved to be effective in killing microbial agents both viral and bacterial and in protecting the human body against various diseases as well as treating some types of cancer.

In our survey, we didn't find any study dealt with the therapeutic effect of Camel's milk against the bad effect of heavy metals, therefore in this study, we tested the effects of oral administration Camel's milk in rats by examining its protective effects against cadmium chloride induced toxicity rats.

\section{MATERIALS AND METHODS}

Camel's milk samples: Milk samples were collected early morning daily from Camel's farm in Abha area (Southeastern region of Saudi Arabia). Milk was collected from camels by hand milking as normally practiced by the farmers. The samples were collected in sterile screw bottles kept in cool boxes until transported to the laboratory.

Animals: White albino rats of both sexes (230-250 g) were supplied by the animal house at the medical faculty of King Khalid University. The rats were housed in standard metal cages (6 rats/cage) and were fed a stock diet containing 50 wheat, 21 corn, 20 soybean, 8 concentrated proteins and $1 \%$ a mixture of salts, vitamins and dicalcium phosphate. Water was supplied ad libitum. These rats were kept at room temperature $22^{\circ} \mathrm{C}$ before and during the experiments.

Three groups of rats each of 6 male rats were used; all treatment were given orally using cavage needle and were treated as follows:

Group 1: Given a daily dose of $2 \mathrm{~mL}$ normal saline (control group)

Group 2: Given a daily $2 \mathrm{~mL}$ dose of a solution contains $10 \mathrm{mg} \mathrm{kg}^{-1}$ body weight of cadmium chloride orally for 3 weeks.

Group 3: Given a daily $2 \mathrm{~mL}$ dose of a solution contains $10 \mathrm{mg} \mathrm{kg}^{-1}$ body weight of cadmium chloride dissolved in camel milk orally for 3 weeks.

Collection of blood serum: At the end day 21, the animals were subjected to over night fasting and then were scarified by cervical dislocation. Blood samples were collected directly into plain tubes and then were centrifuged at $3000 \mathrm{rpm}$ for $10 \mathrm{~min}$ to obtain serum.

Preparation of liver homogenate: The liver was quickly removed, washed in ice-cold, isotonic saline and blotted individually on ash-free filter paper, The tissues were then homogenized in $0.1 \mathrm{M}$ Tris- $\mathrm{HCl}$ buffer, pH 7.4 using a Potter-Elvejham homogenizer at $4^{\circ} \mathrm{C}$ with a diluting factor of 4 , the crude tissue homogenate was then centrifuged at a speed of $9000 \mathrm{rpm}$ for $15 \mathrm{~min}$ in cold centrifuge, the supernatant was kept at $-20^{\circ} \mathrm{C}$ for estimation of TBARS, lipid hydroperoxides, reduced glutathione (GSH), Superoxide Dismutase ( SOD) and Catalase Activity (CAT).

Physiological and biochemical analyses: Hemoglobin was determined by the method described by Drabkins and Austin ${ }^{[37]}$. Urea was determined by the method of Natelson ${ }^{[38]}$. The albumin content was estimated by the method described by Reinhold ${ }^{[39]}$. Iron levels were determined using commericial kits (Human, USA) according to manufacturer's instruction. The enzymes, Aspartate Aminotransferase (AST), Alanine Aminotransferase (ALT) and Alkaline Phosphatase (ALP), were assayed using commercial kits (Quimica Clinica Aplicada S.A. Spain). Calcium, Sodium and chloride were assayed using an analysis kit (Quimica Clinica Aplicada SA Spain) according to the manufacturer's instructions.

\section{Estimation of lipid peroxidation and oxidative stress} parameters:

Estimation of TBARS: The concentration of Thiobarbituric Acid Reactive Substances (TBARS) in the liver homogenate was determined by the method of $\mathrm{Okhawa}^{[40]}$. In brief, the reaction mixture contained $0.1 \mathrm{~mL}$ of tissue homogenate, $0.2 \mathrm{~mL}$ of sodium dodecyl sulfate, $1.5 \mathrm{~mL}$ of acetic acid and $1.5 \mathrm{~mL}$ of aqueous solution of TBA. The $\mathrm{pH}$ of $20 \%$ acetic acid was pre-adjusted with $1 \mathrm{M} \mathrm{NaOH}$ to 3.5 . The mixture was made up to $4 \mathrm{~mL}$ with distilled water and heated at $95^{\circ} \mathrm{C}$ for $1 \mathrm{~h}$, in a water bath. After cooling, $1 \mathrm{~mL}$ of distilled water and $5 \mathrm{~mL}$ of mixture of $\mathrm{n}$-butanol and pyridine (15:1) were added and mixture was shaken vigorously on a vortex mixer. The absorbance of the upper organic layer was read at $532 \mathrm{~nm}$. The values were expressed as $\mathrm{mM} / 100 \mathrm{~g}$ of tissues.

Estimation of lipid hydroperoxides: The estimation of lipid Hydroperoxides (HP) was done by the method of Jiang $^{[41]}$, in which $0.1 \mathrm{~mL}$ of tissue homogenate (supernatant) was treated with $0.9 \mathrm{~mL}$ of fox reagent 
( $88 \mathrm{mg}$ of butylated hydroxytoluene, $7.6 \mathrm{mg}$ of xylenol orange and $9.8 \mathrm{mg}$ of ammonium iron sulfate added to $90 \mathrm{~mL}$ of methanol and $10 \mathrm{~mL}$ of $250 \mathrm{mM}$ sulfuric acid) and incubated at $37^{\circ} \mathrm{C}$ for $30 \mathrm{~min}$. the color developed was read at $560 \mathrm{~nm}$. Lipid hydroperoxides were expressed as $\mathrm{mM} / 100 \mathrm{~g}$ of tissues.

Estimation of reduced glutathione: The GSH content of the liver homogenate was measured at $412 \mathrm{~nm}$ using the method of Sedlak and Lindsay ${ }^{[42]}$. The homogenate was precipitated with $50 \%$ trichloraacetic acid and then centrifuged at $1000 \mathrm{rpm}$ for $5 \mathrm{~min}$. The reaction mixture contained $0.5 \mathrm{~mL}$ of supernatant, $2.0 \mathrm{~mL}$ of Tris-EDTA buffer (0.2 M; pH 8.9) and $0.1 \mathrm{~mL}$ of $0.01 \mathrm{M} 5.5^{\prime}-$ dithio-bis-2-nitrobenzoic acid. The solution was kept at room temperature for $5 \mathrm{~min}$ and then read at $412 \mathrm{~nm}$ on the spectrophotometer. The values were expressed as $\mathrm{mg} / 100 \mathrm{~g}$ of tissues.

Estimation of Catalase activity: Catalase activity was assayed according to the method of $\mathrm{Aebi}^{[43]}$. Supernatant $(50 \mu \mathrm{L})$ was added to a $3.0 \mathrm{~mL}$ cuvette that contained $1.95 \mathrm{~mL}$ of $50 \mathrm{mM}$ phosphate buffer $(\mathrm{pH}$ 7.0). $1.0 \mathrm{~mL}$ of $30 \mathrm{mM}$ hydrogen peroxide was added and changes in absorbance were followed for $30 \mathrm{sec}$ at $240 \mathrm{~nm}$ at $15 \mathrm{sec}$ intervals. Catalase activity was expressed as $\mathrm{U}$ per $\mathrm{mg}$ protein.

Estimation of SOD activity: The activity of SOD in tissue was assayed by the method of Kakkar ${ }^{[44]}$. The assay mixture contained $1.2 \mathrm{~mL}$ sodium pyrophosphate buffer ( $\left.\mathrm{pH} 8.3,0.025 \mathrm{~mol} \mathrm{~L} \mathrm{~L}^{-1}\right), 0.1 \mathrm{~mL}$ phenazine methosulphate $\left(186 \mathrm{~m}\right.$ mol $\left.\mathrm{L}^{-1}\right), 0.3 \mathrm{~mL}$ NBT (300 mmol L $\left.\mathrm{m}^{-1}\right), 0.2 \mathrm{~mL} \mathrm{NADH}\left(780 \mathrm{~m} \mathrm{~mol} \mathrm{~L}^{-1}\right)$ and approximately diluted enzyme preparation and water in a total volume of $3 \mathrm{~mL}$. After incubation at $30^{\circ} \mathrm{C}$ for $90 \mathrm{sec}$, the reaction was terminated by the addition of $1.0 \mathrm{~mL}$ of glacial acetic acid. The reaction mixture was stirred vigorously and shaken with $4.0 \mathrm{~mL}$ nbutanol. The color intensity of the chromogen in the butanol layer was measured at $560 \mathrm{~nm}$ against n-butanol.

Statistical analysis: Data are given as the mean \pm SD. Student's t-test was used to determine if the difference observed among various treatment groups at individual time points was significant.

\section{RESULTS}

Variation in total serum albumin: Data in Table 1 showed that, orally administrated cadmium chloride caused highly significant decreases in serum total albumin of rats compared to control animals. On the other hand, the addition of Camel's milk to cadmium chloride caused a significant increase in levels of albumin in rats in comparing to rats received cadmium chloride alone.

Effect of treatment on serum urea of the rats: Data in Table 1 revealed that, highly significant increased in serum urea concentration through the experimental period of rats under administration of cadmium chloride compared with the control group. While adding Camel's milk to the cadmium chloride resulted in a significant decreased of serum urea compared with rats treated with cadmium alone.

Table 1: Levels of albumin, Urea, hemoglobin, Iron, calcium, sodium and chloride in serum of control and experimental groups of rats

\begin{tabular}{lccc}
\hline Parameters & Control & \multicolumn{1}{c}{ Cadmium } & Cadmium+milk \\
\hline Albumin mol L & $613.60 \pm 12$ & $434.00 \pm 10^{*}$ & $595.80 \pm 13.5^{*}$ \\
Urea m mol L & $3.78 \pm 0.4$ & $9.70 \pm 0.85^{*}$ & $3.96 \pm 0.6^{*}$ \\
Hemoglobin & $2.00 \pm 0.02$ & $1.10 \pm 0.08^{*}$ & $1.90 \pm 0.15^{*}$ \\
$\mathrm{~m} \mathrm{~mol} \mathrm{~L}^{-1}$ (blood) & & & \\
Iron $\mu \mathrm{mol} \mathrm{L}$ & $24.00 \pm 1.1$ & $112.50 \pm 8.9^{*}$ & $26.60 \pm 5.9^{*}$ \\
Calcium m mol L & $2.30 \pm 0.12$ & $1.30 \pm 0.2^{*}$ & $2.21 \pm 0.04^{*}$ \\
Sodium m mol L & $149.60 \pm 4.5$ & $268.60 \pm 5.6^{*}$ & $147.20 \pm 2.4^{*}$ \\
Chlorid m mol L & $105.10 \pm 1.2$ & $190.10 \pm 7.4^{*}$ & $104.30 \pm 1.6^{*}$ \\
\hline
\end{tabular}

Values are given as mean \pm SD for groups of six animals each. Values are statistically significant at $* \mathrm{P}<0.05$. Cadmium treated rats were compared with control rats; Camel's milk Cadmium treated rats were compared with Cadmium treated rats

Effect of treatment on the blood hemoglobin in the rats: As shown in Table 1, exposure of rats to cadmium chloride resulted in highly significant decreased in blood hemoglobin levels compared with its levels in control group. Adding Camel's milk to cadmium chloride significantly increased the lower levels of hemoglobin as compared to rats received cadmium chloride alone.

Changes in serum levels iron in the rats: As shown in Table 1; the obtained results indicated that rats exposed to cadmium chloride resulted in a significant increased in serum iron concentration in comparing with the control group. Administration of Camel's milk with cadmium chloride to the rats resulted in highly significant decrease in serum iron concentration in the rats compared with the rats orally administered cadmium alone.

Change in calcium concentration of the serum of experimental groups: Results in Table 1, showed that, administering cadmium chloride solution to the rats 
resulted in a statistically significant decrease of calcium concentration in their serum in comparing with the control group. While rats' orally administrated solution of Camel's milk with cadmium chloride significantly raised calcium concentration in blood of rats in relation to the rats administered cadmium chloride alone.

Changes in the serum sodium and chloride: An effect of cadmium chloride administrated to the rats on serum sodium and chloride was showed in Table 1. Orally administrated of cadmium chloride to rats' results in a statistically highly significant increased of sodium and chloride concentration in rats serum in relation to the control group. On contrast, adding Camel's milk to cadmium chloride decreased the high levels of sodium and chloride concentration in serum of rats as compared to rats administered cadmium chloride only.

\section{Alanine Aminotransferase, Aspartate Aminotransferase and Alkaline Phosphatase} Activities (ALT, AST, ALP): Results in Table 2 showed that, administering of cadmium chloride to rats resulted in a statistically significant increased of alanine aminotransferase, aspartate aminotransferase and alkaline phosphatase activities in the rat's serum comparing with the control group. On contrast, adding Camel's milk to cadmium chloride produced a significant decrease in the levels of alanine aminotransferase, aspartate aminotransferase and alkaline phosphatase in relation to rats received cadmium chloride alone.

Table 2: Levels of ALT, AST and ALP in serum of control and experimental groups of rats

\begin{tabular}{llcc}
\hline Parameters & Control & Cadmium & Cadmium + milk \\
\hline AST $\left(\mathrm{U} \mathrm{L} \mathrm{L}^{-1}\right)$ & $68.100 \pm 1.2$ & $210.2 \pm 6.2^{*}$ & $65.5 \pm 2.2^{*}$ \\
ALT $\left(\mathrm{U} \mathrm{L} \mathrm{L}^{-1}\right)$ & $36.0 .9 \pm 2.6$ & $120.3 \pm 5.4^{*}$ & $33.1 \pm 4.0^{*}$ \\
ALP $\left(\mathrm{IU} \mathrm{L}^{-1}\right)$ & $75.700 \pm 1.3$ & $211.9 \pm 11.6^{*}$ & $77.0 \pm 1.8^{*}$
\end{tabular}

Values are given as mean \pm SD for groups of six animals each. Values are statistically significant at $* \mathrm{p}<0.05$. Cadmium treated rats were compared with control rats; Camel's milk Cadmium -treated rats were compared with Cadmium treated rats

Table 3: Levels of lipid peroxides, hydroperoxides and reduced glutathione in liver of control and experimental groups of rats

\begin{tabular}{|c|c|c|c|}
\hline Parameters & Control & Cadmium & Cadmium + milk \\
\hline $\begin{array}{l}\text { TBARS (m M/100g } \\
\text { of tissue) }\end{array}$ & $0.75 \pm 0.02$ & $2.60 \pm 0.10^{*}$ & $0.77 \pm 0.01^{*}$ \\
\hline $\begin{array}{l}\text { Hydroperoxides } \\
\text { (mM/100g of tissue) }\end{array}$ & $73.21 \pm 0.83$ & $104.71 \pm 1.11^{*}$ & $79.11 \pm 0.32 *$ \\
\hline $\begin{array}{l}\text { Glutathione }(\mathrm{GSH}) \\
\text { (mg/100 g of tissue) }\end{array}$ & $41.9 \pm 1.67$ & $21.65 \pm 0.98^{*}$ & $40.20 \pm 2.0^{*}$ \\
\hline \multicolumn{4}{|c|}{$\begin{array}{l}\text { Values are given as mean } \pm \text { SD for groups of six animals each. } \\
\text { Values are statistically significant at } * \mathrm{p}<0.05 \text {. Cadmium treated rats } \\
\text { were compared with control rats; Camel's milk Cadmium -treated rats } \\
\text { were compared with Cadmium treated rats }\end{array}$} \\
\hline
\end{tabular}

Table 4: Levels of Superoxide Dismutase (SOD) and Catalase (CAT) in liver of control and experimental groups of rats

\begin{tabular}{llll}
\hline Parameters & Control Cadmium & Cadmium + milk
\end{tabular}

SOD (U mg ${ }^{-1}$ of protein)* $10.0 \pm 0.02 \quad 5.12 \pm 7.2 * \quad 9.85 \pm 3.2^{*}$

$\mathrm{CAT}\left(\mathrm{U} \mathrm{mg}^{-1}\right.$ of protein) ${ }^{\#} \quad 88.0 \pm 3.1 \quad 44.30 \pm 2.47 * \quad 83.81 \pm 5.0^{*}$

*: Units/mg protein (amount of enzyme required to inhibit 50\% reduction of NBT); \#: Units $\mathrm{mg}^{-1}$ protein ( $\mu \mathrm{m}$ of $\mathrm{H}_{2} \mathrm{O}_{2}$ decomposed $\mathrm{mg}$ protein ${ }^{-1} \mathrm{~min}^{-1}$ ) Values are given as mean \pm SD for groups of six rats each. Values are statistically significant at $* \mathrm{p}<0.05$. Cadmium treated rats were compared with control rats; camel's milk cadmiumtreated rats were compared with Cadmium treated rats

Lipid peroxides, hydroperoxides and reduced glutathione: Table 3 shows the concentration of TBARS, hydroperoxides and reduced glutathione in liver of control and experimental groups of rats. The levels of TBARS and hydroperoxides in Cadmium chloride treated rats were significantly higher than control rats, whereas rats treated with Camel's milk with Cadmium chloride restored the altered values to the normalcy. The decreased concentration of GSH was observed in Cadmium chloride treated rats, Administration of Camel's milk with Cadmium chloride tended to bring the GSH level to normal levels.

Superoxide dismutase and Catalase activities: SOD and CAT activities (Table 4) were significantly reduced in Cadmium chloride treated rats when compared to control rats, their levels came to normal in the group of rats administered a solution of Camel's milk and cadmium chloride.

\section{DISCUSSION}

Cadmium is one of the most dangerous occupational and environmental toxins. It is found in drinking water, atmospheric air and even in food. Products of vegetable origin are the main carrier of cadmium compounds in food ${ }^{[6]}$. Having been absorbed from the alimentary tract, cadmium forms durable combinations with the protein thionein, forming metallothioneins which play an important role in further metabolism of this metal. It seems that the toxicity of this metal on one hand lies in a direct action of free cadmium ions not bound with metallothionein, while on the other hand, in forming reactive radicals being able to change functions and structure of many system and $\operatorname{organs}^{[6,7]}$. Until now in treating intoxication with this metal, chelating Compounds have been used, burdened with numerous undesirable symptoms. The present study evaluates the protective effect of Camel's milk against toxicity induced by Cadmium in male rats.

Albumin is the most abundant protein in human plasma, representing $55-65 \%$ of total protein. It synthesized in the liver at a rate that is dependent on 
protein intake subject to feedback regulation by the plasma albumin level. Little albumin is filtered through the kidney glomerali and most of that is reabsorbed by proximal tubule cells and degraded by their lysosomal enzymes into fragment that are returned to the circulation. In this study there was a significant decrease in serum albumin of rats treated with cadmium chloride alone as compared to the control rats received normal saline, indicating poor liver functions or impaired synthesis, either primary as in liver cells damage or secondary to diminished protein intake and reduced absorption of amino acids caused by a malabsorption syndromes or malnutrition. Other interpretation may cadmium caused loss protein in urine, due to nephritic syndrome, chronic glomerulonephritis. On the other hand, the results in the present study showed that rats fed on Camel's milk and cadmium chloride together restored and increased the reduced albumin levels in blood as compared with the rats received cadmium only.

Urea levels in the serum of all groups of rats is shown in Table 1; Urea levels were highly significantly increased in rats administrated orally with cadmium chloride only comparing with the control rats receiving normal saline. As a result of cadmium activity, one notices renal tubule damage and then glomerular filtration impairment ${ }^{[45]}$. This may account for the increase of urea concentration in the animals receiving cadmium chloride. The damaging effect of cadmium on kidneys has also been described by other authors ${ }^{[46]}$. Some occupational studies have reported increased serum concentrations of urea indicating reduced Glomerular Filtration Rate (GFR) in cadmium-exposed rats $^{[47,48]}$. Cadmium dose remained the important predictor of serum urea even after controlling for age, blood pressure, body size and other extraneous factors $^{[4]]}$. It has been suggested that cadmium-induced tubular damage leads to a certain degree of interstitial nephritis, which in turn results in a decreased GFR ${ }^{[49]}$. It has also been proposed that cadmium exerts a direct toxic effect on the glomerulus ${ }^{[47]}$ Also, the present studies agree with Shibutani et al. ${ }^{[4 \dot{5}]}$, who reported that cadmium can affect on renal tubules damage and then glomerular filtration impairment. In the present investigations, administration of Camel's milk with cadmium chloride significantly decreases and brought the concentration of urea in the rat's serum to near normal levels.

A result of exposure to cadmium there develops, among others, hypochromic anemia. Several mechanisms leading to anemia have been suggested. Cadmium may compete with iron, leading to the occurrence of anemia due to iron deficiency, whereas on the other hand renal failure, developing under the influence of cadmium, results in erythropoietin deficiency which may causes normochromic and normocytic anemia without a proportional increase of reticulocytes ${ }^{[50,51]}$. Chun et al. ${ }^{[52]}$ are of the opinion that cadmium ions significantly affect regulatory genes for erythropoietin, which may be the cause of inhibiting its expression. As shown in Table 1, Blood hemoglobin concentration may be diminished because of hemolysis or because of impaired blood formation in bone marrow in rats administrated cadmium chloride compared with hemoglobin levels in blood of control group rats receiving normal saline. Moreover, Cadmium inhibits the bone marrow to make hemoglobin by interfering with several enzymatic steps in the heme synthesis. Also Cadmium has been found to have direct effect on blood hemoglobin by decreasing its formation as results from two basic red cell defects; shortened life span and impaired heme synthesis. The mechanisms by which synthesis of the red cell pigment heme is inhibited by cadmium involves at least two enzymes, a cytoplasm one (delta-aminoleuvinic acid) at the beginning of heme synthesis and a mitochondrial one, ferrochelatase, at the end of heme synthesis ${ }^{[53]}$. Ferritin is both a very efficient iron trap and a readily an available source of iron for metabolic requirements and for formation of hemoglobin and other heme proteins. The minute concentration of ferritin in serum is an indicator of total body storage iron. Liver injury results in release of relatively enormous amounts of ferritin into plasma, resigning the serum ferritin concentration and serum iron concentration several hundred times, these results were shown by our study in the rats administered cadmium chloride orally. As shown in Table 1, rats orally administrated Camel's milk with cadmium chloride resulted in as significant increased blood hemoglobin and decreased serum iron compared with the results in rats orally administered cadmium chloride alone.

Cadmium affects bone development and mineralization $^{[17]}$ and has an antagonistic activity in calcium metabolism ${ }^{[5]}$. In the present study, administering cadmium chloride to rats resulted in a statistically significant decrease of calcium concentration in serum of rats in relation to the control group. For a proposed mechanism for the decreased calcium absorption and negative calcium balance seen in rats exposed to cadmium is that this metal inhibits activation of vitamin $\mathrm{D}$ in the renal cortex ${ }^{[54]}$. Cadmium inhibits vitamin D-stimulated intestinal calcium transport in rats ${ }^{[55,56]}$. Renal conversion of 25hydroxycholealceferol to $1, \quad 25$ dihydroxycholecalceferol in rats is inhibited by low and a high dietary concentration of cadmium ${ }^{[57]}$. The present results agree with a series of studies in Japan, described in detail in $\mathrm{WHO}^{[58]}$, on the effect of dietary cadmium in monkeys, a dose of $\left(30 \mathrm{mg} \mathrm{kg}^{-1}\right.$ bwt) was found to worsen osteomalacic changes in the bones of animals fed diets with low concentration protein, calcium and vitamin D. Several studies on the effects of oral administration of cadmium on bone and calcium metabolism showed decreased calcium content in bone 
and increased urinary excretion of cadmium that resulted in decalcification and cortical atrophy in the skeleton, associated with renal cortical concentrations ${ }^{[59-61]}$. In the present study, Camel's milk improved the negative effect of cadmium on calcium metabolism and demonstrate protective action against the changes of calcium metabolism by cadmium, Calcium levels significantly increased in the rats orally administered Camel's milk with cadmium compared to rats received cadmium alone orally. The mechanism of the beneficial effect of Camel's milk may be due to high calcium content in the milk or by the positive effect of camel's milk on the vitamin D formation and on the functions of this vitamin on the metabolism of the calcium, in which vitamin D formed and stimulate calcium absorption from the small intestine and restore serum calcium concentration.

The plasma chloride values are useful guide to acid-base status and the major anion present in the extracellular fluid is closely related to that of sodium. Administering cadmium chloride to the rats resulted in a statistically significant increase sodium and chloride in serum of rats as compared to the control group. While adding the Camel's milk to cadmium chloride normalized the sodium and chloride concentration in rat's serum.

Cadmium injection at dosage $10 \mathrm{mg} \mathrm{day}^{-1}$ for 21 days showed severe hepatic damage noticed by the marked increase in the serum activity of aminotransferases (ALT, AST and ALP). These characteristic features of Cadmium-induced liver toxicity were similar to those previously reported by other investigators ${ }^{[62,63]}$. Several mechanisms have been suggested for the induction of Cadmium-associated hepatotoxicity ${ }^{[62]}$. The two enzymes ALT and AST are found in the liver and have been widely used for diagnostic purposes. AST is present in both the mitochondria and cytosol of liver cells, while (ALT) is found in the cytosol only. Liver cells damage releases these enzymes into the extracellular fluid and results in increased plasma levels of transaminase activity. The Alkaline Phosphates (ALP) are a group of glycoprotein enzymes that bound to alkaline PH. ALP activity is found in virtually all tissues, particularly bone, liver, kidney, intestine, adrenal and placenta. In addition, Johnson $^{[64]}$ hypothesized that, in liver Alkaline Phosphatase (ALP) is found at two distinct sites on the sinusoidal surface of the hepatocyte and in the microvilli of the bile canaliculi and ducts. ALP is also found in a number of other body tissues; thus, the plasma ALP activity is not specific for the liver. oral Administration of cadmium chloride to rats resulted in a statistically highly significant increase in the levels of these enzymes: ALT, AST and ALP in the serum when compared with the control group received normal saline. On the other hand, Administration of Camel's milk with the cadmium restored the levels of these enzymes in the serum of the rats as an indication of protective effect of Camel's milk against liver damage induced by cadmium.

In this study, Cadmium treated rats showed not only a significant increase in TBARS and hydroperoxides level, but also decreased the activity of antioxidative system elements (superoxide dismutase, catalase) as well as glutathione content and leads to the production of oxygen reactive forms. These results correlate well with other reports where Cadmium has been shown to up regulate oxidative stress marker such as TBARS and decrease the activity of antioxidants such as GSH and $\operatorname{SOD}^{[15,65]}$. Oral administration of camel's milk with the cadmium chloride significantly reduced the lipid peroxidation biomarker (TBARS and Hydroperoxides) and returned them to their normal levels; it also normalized the levels of both enzymatic and non-enzymatic components of antioxidant system (GSH, SOD and CAT) in the liver.

The protective effect of Camel's milk against Cadmium-induced toxicity, oxidative stress and tissue damage in this study could be attributed to its antioxidant and possible chelating effects on cadmium. It has been reported that camel's milk contain high levels of Vitamins $\mathrm{C}, \mathrm{A}, \mathrm{B} 2$ and $\mathrm{E}$ and very rich in magnesium $^{[33]}$. These vitamins are antioxidants found to be useful in preventing the tissues injury caused by toxic agent. Magnesium protects cells from heavy metals such as aluminum, mercury, lead, cadmium, beryllium and nickel, which explains why remineralization is so essential for heavy metal detoxification and chelating. Magnesium deficiency $(\mathrm{MgD})$ has been associated with production of reactive oxygen species ${ }^{[66]}$. Magnesium protects the cell against oxyradical damage and assists in the absorption and metabolism of $B$ vitamins, vitamin $C$ and $E^{[67]}$, which are antioxidants important in cell protection. Recent evidence suggests that vitamin E enhances glutathione levels and may play a protective role in magnesium deficiency-induced cardiac lesions ${ }^{[67]}$. Also it has been reported that magnesium is very essential for biosynthesis of glutathione, because the enzyme Glutathione synthetase requires $\gamma$-glutamyl cysteine, glycine, ATP and magnesium ions to form glutathione $^{[68]}$. An other interpretation for the improvement of the parameters of the present investigation may be due to the decrease of cadmium accumulation in liver and kidneys in the rats receiving Camel's milks in addition to cadmium. Among the possible mechanisms, it might occur that Camel's milks reduced the renal uptake of cadmium by competition for a common transporter and demonstrates protective actions against the damages of hepatocytes and renal function during cadmium intoxication in the rats. 


\section{CONCLUSION}

Our results indicate that Camel's milk have a protective effect against cadmium induced toxicity in rats.

\section{REFERENCES}

1. Tephyly, T.R., G. Wagner, R. Sidman and W. Piper, 1978. The effects of metals on hem biosynthesis and metabolism. Fed. Toxicol. Sci., 26: 337-358. http://www.ncbi.nlm.nih.gov/pubmed/338364

2. Deur, C.D., M.D. Stone and E.P. Frenkel, 1981. Trace metals in hematopoiesis. Am. J. Hemato., 11: 309-331. DOI: 10.1002/ajh.2830110313

3. Wong, K.L. and C.D. Klaassen, 1982. Neurotoxic effects of cadmium in young rats. Toxicol. Applied Pharmacol., 63: 330-337. http://www.ncbi.nlm.nih.gov/pubmed/7101297

4. Vallee, B.L. and D.D. Ulmr, 1972. Biochemical effects of mercury, cadmium and lead. Annu. Rev. Biochem., 41: 91-128. http://www.ncbi.nlm.nih.gov/pubmed/4570963

5. McDowell, L.R., 1992. Minerals in animal and human Nutrition. Academic press, New York, ISBN: 0-12-483369-1, pp: 524.

6. Jarup, L., L. Hellstrom, T. Alfven, M.D. Carlsson and A. Grubb, et al., 2000. Low level exposure to cadmium and early kidney damage: The OSCAR study. Occup. Environ. Med., 57: 668-672. http://www.ncbi.nlm.nih.gov/pubmed/10984338

7. Kowalczyk, E., K. Anna, F. Pawel, K. Maria, N. Jan, B. Jan, K. Jozef and T. Piotr, 2003. Effect of anthocyanins on selected biochemical parameters in rats exposed to cadmium. Acta Biochem. Polonica, 50: 543-548.

http://www.ncbi.nlm.nih.gov/pubmed/12833179

8. Lewis, R., 1997. Occupational Exposures. In: Occupational and Environmental Medicine, LaDou, J. (Ed.). 2nd Edn., Prentice-Hall, International, Inc., ISBN: 0838572162, pp: 412-414.

9. Ochi, T., K. Takashi and M. Ohsawa, 1987. Indirect evidence for the induction of a pro oxidant state by cadmium chloride in cultured mammalian cells and a possible mechanism for the induction. Mut. $\quad$ Res., 180: 257-266. http://www.ncbi.nlm.nih.gov/pubmed/3657823

10. Sarkar, S., P. Yadav, D.J. Bhatnagar, 1997. Cadmium-induced lipid peroxidation and the antioxidant system in at erythrocytes: The role of antioxidants. Trace Elem. Med. Biol., 11: 8-13. http://cat.inist.fr/?aModele=afficheN\&cpsidt=2740396
11. Novelli, E.L., E.P. Vieira, N.L. Rodrigues, B.O. Ibas, 1998 Risk assessment of cadmium toxicity on hepatic and renal tissues of rats. Environ Res., 79: 102-105. http://www.ncbi.nlm.nih.gov/pubmed/9841808

12. Paltanaviciene, A., D. Zabulyte, J. Kalibatas, V. Drebickas, A. Juozulynas and A. Jurgelenas, 2006. General toxicity studies of the cadmium and benzo (a) pyrene complexes. Trace Elem. Electrolyt., 23: 134-139.

http://d.wanfangdata.com.cn/NSTLQK_NSTL_QK 12530523.aspx

13. Bhattacharjer, D., T.K. Shetty, K. Sundaram, 1979. studies on the distribution of 115 mcadmium in mice tissues. Indian J. Exp. Biol., 17: 4-6.

14. Gutteridge, J.M., 1995. Lipid peroxidation and antioxidants as biomarkers of tissue damage. Clin. Chem., 41: 1819-1828.

http://www.clinchem.org/cgi/content/abstract/41/12/1819

15. Stohs, S.J., D. Bagchi,, E. Hassoun and M. Bagchi, 2001. Oxidative mechanisms in the toxicity of chromium and cadmium ions. J. Environ. Pathol. Toxicol. Oncol., 20: 77-88. http://www.ncbi.nlm.nih.gov/pubmed/11394715

16. Bagchi, D., M. Bagchi, E. Hassoun and S.J. Stohs, 1996. Cadmium induced excretion of urinary lipid metabolites, DNA damage, glutathione depletion and hepatic lipid peroxidation in Sprague-Dawley rats. Biol. Trace Elem. Res., 52: 143-154. http://cat.inist.fr/?aModele $=$ afficheN\&cpsidt=10947706

17. Khandelwal, S., N. Agnihotri and S.K. Tandon, 1991. Biochemical response to cadmium dose-time effect. Boil. Trace Elem. Res., 29: 157-164. http://www.ncbi.nlm.nih.gov/pubmed/1713472

18. Ryan, P.B., N. Huet and D.L Maclntosh, 2000 Longitudinal investigation of exposure to arsenic, cadmium and lead in drinking water. Environ. Health Perspect., 108: 731-735. http://www.pubmedcentral.nih.gov/articlerender.fc gi?artid= 1638277

19. Yamano, T., S.D. Kosanke and L.E. Rikans, 1999. Attenuation of cadmium-induced liver injury in senescent male Fischer 344 rats: Role of metallothionein and glutathione. Toxicol. Applied Pharmacol., $\quad$ 161: 225-230. http://www.ncbi.nlm.nih.gov/pubmed/10620479

20. Yiin, S.J., C.L. Chern, J.Y. Sheu, W.C. Tseng and T.H. Lin, 1999 Cadmium induced renal lipid peroxidation in rats and protection by selenium. $\mathrm{J}$. Toxicol. Environ. Health, 57: 403-413. http://www.ncbi.nlm.nih.gov/pubmed/10478822 
21. Pinot, F., S.E. Kreps, M. Bachelet, P. Hainaut, M. Bakonyi and B.S. Polla, 2000. Cadmium in the environment: Sources, mechanisms of biotoxicity and biomarkers. Rev. Environ. Health, 15: 299-323. http://www.ncbi.nlm.nih.gov/pubmed/11048333

22. Saure, J.M., M.P. Waalkes, S.B. Hooser, R.K. Kuester, C.A. Mcqueen and I.G. Sipes, 1997. Suppeesion of kupffer cell function prevents cadmium induced hepatocellular necrosis in the male Sprague-dawley rat. Toxicology, 121: 155-164. http://www.ncbi.nlm.nih.gov/pubmed/9230447

23. Blasco, J. and J. Puppo, 1999. Effect of heavy metals $(\mathrm{Cu}, \mathrm{Cd}$ and $\mathrm{Pb})$ on aspartate and alanine aminotransferase in ruditapes philippinarum. Comp. Biochem. Physiol. Pharmacol. Toxicol. Endocrinol, 122: 253-263. http://direct.bl.uk/bld/PlaceOrder.do?UIN=057111 $173 \&$ ETOC $=$ RN\& from $=$ searchengine

24. Sherlock, S. and J. Dooley, 2002. Diseases of Liver and Biliary System. Blackwell Science, London, ISBN: 0632055820, pp: 706.

25. Lee, J.R., J.P. Sook, K.K. Young, K.J. Seon and S. Jungcheol et al., 2009. Hepatoprotective activity of licorice water extract against cadmium induced toxicity in rats. eCAM., 6: 195-201. http://ecam.oxfordjournals.org/cgi/content/abstract/ nem078

26. Shaikh, Z.A., S.A. Jordan and W.F. Tang, 1999. Protection against chronic cadmium toxicity by caloric restriction. Toxicology, 133: 93-103. http://www.ncbi.nlm.nih.gov/pubmed/10378476

27. Gale, G.R., A.B. Smith and E.M. Walker, 1981. Diethyldithiocarbomate in the treatment of acute cadmium poisoning. Ann. Clin. Lab. Sci., 11: 476-483. http://www.annclinlabsci.org/cgi/content/abstract/1 $1 / 6 / 476$

28. Geyer, R.A., 1995. Transpacental Transfer of Lead and Cadmium. In: Toxicology of Metals: Biochemical Aspects, Goyer, R.A. and M.G. Cherian (Eds.). Springer-Verlag, Heidelberg, ISBN: 3540582819, pp: 1-13.

29. Aughey, E., G. Fell, R. Scott and M. Black, 1984. Histopathology of early effects of oral cadmium in the rat kidney. Environ. Health Perspect., 54: 153-161. http://www.jstor.org/stable/3429802

30. Brzoska, M.M., M. Kaminski, D. Supernak, K. Zwierz and J. Moniuszko, 2003. Changes in the Structure and function of the kidney of rats chronically exposed to cadmium. Biochemical and histopathological studies. Arch. Toxicol., 77: 344-352. DOI: $10.1007 / \mathrm{s} 00204-003-0451-1$
31. Hassoun, E.A. and S.J. Stohs, 1996. Cadmiuminduced production of supen and nitric oxide xideation DNA single strank breaks and lactate dehydrogenase leakage. Toxicology, 112: 219-226. http://cat.inist.fr/?aModele $=$ afficheN\&cpsidt $=3223$ 779

32. Dally, H. and A. Harwing, 1997. Induction and repair inhibition of oxidative DNA damage by nickel, Zinc protects renal function during cadmium intoxication in the rat and cadmium in mammalian cells. Carcinogenesis, 18: 1021-1026. http://carcin.oxfordjournals.org/cgi/content/abstract $/ 18 / 5 / 1021$

33. Knoess, K.H., 1979. Milk production of the dromedary. Proceeding of the 1st International Symposium on Camels, (ISC'79), Sudan, pp: 201-214.

34. Rao, M.B., R.C. Gupta and N.N. Dastur, 1970. Camels' milk and milk products. Indian J. Dairy Sci., 23: 71-78.

35. Agrawal, R.P., S.C. Swami, R. Beniwal, D.K. Kochar, M.S. Sahani, F.C. Tuteja and S.K. Ghouri, 2003. Effect on camel milk on glycemic control, lipid profile and diabetes quality of life in type-1diabetes: A randomized prospective controlled cross over study. Indian J. Anim. Sci., 73:1105-1110. http://cat.inist.fr/?aModele $=$ afficheN\&cpsidt $=15295836$

36. Agrawal, R.P., S.C. Swami, R. Beniwal, D.K. Kochar and R.P. Kothari, 2002. Effect of camel milk on glycemic control, risk factors and diabetes quality of life in type-1 diabetes: A randomised prospective controlled study. Int. J. Diab. Devel Count.,22:1-5.

http://www.kamelenmelk.nl/paginas/diabetes.pdf

37. Drabkin, D.L. and J.H. Austin, 1932. Spectrophotometer studies for common hemoglobin derivatives in human; dog and rabbit. J. Biol. Chem., 98: 719-725. http://www.jbc.org/cgi/reprint/98/2/719

38. Natelson, S., 1957. Microtechniques of Clinical Chemistry for the Routine Laboratory. SpringfieldIllinois, pp: 381.

39. Reinhold, J., 1980. Determination of Serum Total Protein, Albumin and Globulin Fractions by the Biuret Method. In: Practical Clinical Biochemistry, Varley, H., A.H. Gowen and L.M. Bell, 5th Edn., William Heinemann, London, pp: 45-47.

40. Okhawa, H., N. Ohigni and K. Yagi, 1979. Assay of lipid peroxides in animal tissues by thiobarbituric acid reaction. Anal. Biochem., 95: 351-358.

http://www.ncbi.nlm.nih.gov/pubmed/36810 
41. Jiang, Z.Y., J.V. Hunt and S.D. Wolff, 1992. Ferrous ion oxidation in the presence of xylenol orange for detection of lipid hydroperoxides in low density lipoprotein. Anal. Biochem., 202: 384-391. http://www.ncbi.nlm.nih.gov/pubmed/1519766

42. Sedlak, J. and R.H. Lindsay, 1968. Estimation of total protein bound and non-protein sulfhydryl groups in tissue with ellmans reagent. Anal. Biochem., 25: 293-98. http://www.ncbi.nlm.nih.gov/pubmed/4973948

43. Aebi, H., 1974. Catalase. In: Methods of Enzymatic Analysis, Bergmeyer, H.U. (Ed.). Chemic Academic Press Inc., Verlag, New York, ISBN: 352725370X, pp: 673-85.

44. Kakker, P., B. Das and P.N. Viswanathan, 1984. A modified spectrophotometric assay of superoxide dismutase. Ind. J. Biochem. Biophys., 21: 130-132. http://www.ncbi.nlm.nih.gov/pubmed/6490072

45. Shibutani, M.K., S. Mitsumori, H. Satoh, M. Hiratsuka and M. Satoch et al., 2001. Relationship between toxicity and cadmium accumulation in rats given low amounts of cadmium chloride or cadmium-polluted rice for 22 months. J. Toxicol. Sci., 26: 337-358.

http://cat.inist.fr/?aModele $=$ afficheN\&cpsidt=1347 6255

46. Jarup, L., 2002. Cadmium overload and toxicity. Nephrol Dial Transplant., 17: 35-39. http://www.ncbi.nlm.nih.gov/pubmed/11904357

47. Roels, H., R.R. Lauwerys, J.P. Buchet, A.M. Bernard, A. Vos and M. Oversteyns, 1989. Health significance of cadmium induced renal dysfunction. Br. J. Ind. Med., 46: 785-764. http://www.pubmedcentral.nih.gov/articlerender.fc gi?artid=1009864

48. Thun, M.J., A.M. Osorio, S. Schober, W.H. Hannon and W. Halperin, 1989. Nephropathy in Cadmium workers-assessment of risk from airborne occupational cadmium exposure. Br. J. Med., 46: 689-697.

http://www.pubmedcentral.nih.gov/articlerender.fc gi?artid $=1009850$

49. Flinder, C.G., C. Eding, E. Lindberg, B. Kagedal and O. Vesterlarg, 1985. Assessment of renal function in workers previously exposed to cadmium. Br. J. Ind. Med., 42: 754-760. http://www.pubmedcentral.nih.gov/articlerender.fc gi?artid= 1007572

50. Hiratsuka, H., O. Katsuta, N. Toyota, M. Tsuchitani, T. Umemura and F. Marumo. 1996. Chronic cadmium exposure-induced renal anemia in ovariectomized rats. Toxicol. Applied Pharmacol., 137: 228-236.

http://cat.inist.fr/?aModele=afficheN\&cpsidt=3043 761
51. Mackova, N.O., S. Lenikova, P. Fedorocko and P. Brezani, 1996. Effects of cadmium on haemopoiesis in irradiated and nonirradiated mice: Relationship to the number of circulating blood cells and haemopoiesis. Physiol. Res., 45: 101-106.

http://www.ncbi.nlm.nih.gov/pubmed/9496758

52. Chun, Y.S., E. Choi, G.T. Kim, H. Choi, C.H. Kim, M.J. Lee, S. Kim and J.W. Park, 2000. Cadmium blocks Hypoxia-Inducible Factor (HIF)-1-mediated response to hypoxia by stimulating the proteasomedependent degradation of HIF-1alpha. Eur. J. Biochem., 267: 4198-204.

http://www.ncbi.nlm.nih.gov/pubmed/10866824

53. Moore, M.R., A. Goldberg and A.C. Yeung- Laiwah, 1985. Lead effects on the hemebiosynthetic pathway. Ann. N. Y. Acad. Sci., 514: 191-202. DOI: $10.1111 / j .1749-6632.1987 . t b 48774 . x$

54. Nomiyama, K., H. Nomiyama and N. Kameda, 1998. Plasma cadmium metallothionein, a biological exposure index for cadmium induced renal dysfunction, based on the mechanism of its action. Toxicology, 129: 157-68. http://www.ncbi.nlm.nih.gov/pubmed/9772094

55. Ando, M., M. Shimizu, Y. Sayato, A. Tanimura and M. Tobe, 1981. The inhibition of vitamin D Stimulated intestinal calcium transport in rats after continuous oral administration of cadmium. Toxicol. Applied Pharmacol., 61: 297-301. DOI: 10.1016/0041-008x(81)90350-1

56. Pleasants, W., C. Waslien and B. Naughton, 1993. Dietary modulation of the symptoms of cadmium toxicity in rats: Effects of vitamins A, C, D and fluoride. Nutr. Res., 13: 839-850. http://cat.inist.fr/?aModele $=$ afficheN\&cpsidt $=4809$ 294

57. Lorentzon, R. and S.E. Larsson, 1977. Vitamin D metabolism in adult rats at low and normal calcium intake and the effect of cadmium exposure. Clin. Sci. Mol. Med., 53: 439-446. http://www.ncbi.nlm.nih.gov/pubmed/589928

58. WHO, 1992. Cadmium environmental health criteria $134 . \quad$ Geneva. http://www.speciation.net/Public/Links/DB/Links/ detail.html?id=556

59. Kawai, K., K. Fukuda and M. Kimura, 1976. Morphological Alteration in Experimental Cadmium Exposure with Special Reference to the Onset of Renal Lesion. In: Effects and DoseResponse Relationships of Toxic Metals, Nordberg, G.F. (Ed.). Elsevier Scientific, Amsterdam, ISBN: 0444413707, pp: 359-370. 
60. Kelman, B.J., B.K.Walter and G.E. Jarboe, 1978. Effect of dietary cadmium on calcium metabolism in the rat during gestation. Proc. Soc. Exp. Biol. Med., 158:

614-617. http://www.ncbi.nlm.nih.gov/pubmed/693478

61. Jacquillet, G., O. Barbier, M. Cougnon, M. Taue, C. Namorado, D. Martin and J. Reyes, 2006. Zinc protective renal function during cadmium intoxication in the rat. Am. J. Physiol. Renal Physiol., 290:

127-137. http://ajprenal.physiology.org/cgi/content/abstract/ 290/1/F127

62. Rikans, L.E. and T. Yamano, 2000. Mechanisms of cadmium-mediated acute hepatotoxicity. J. Biochem.., $14:$ 110-117. http://www.biomedexperts.com/Abstract.bme/1063 0425/Mechanisms_of_cadmiummediated_acute_hepatotoxicity

63. Tzirogiannis, K.N., G.I. Panoutsopoulos, M.D. Demonakou,R.I.Hereti and K.N. Alexandropoulou et al., 2003. Time-course of cadmium-induced acute hepatotoxicity in the rat liver: The role of apoptosis. Arch. Toxicol., 77: 694-701.

http://cat.inist.fr/?aModele $=$ afficheN\&cpsidt $=1533$ 6700
64. Johnson, P.J., 1989. Role of the standard liver function tests in current clinical practice. Ann. Clin. Biochem., 26: 463-471. http://www.ncbi.nlm.nih.gov/pubmed/2694908

65. Nigma, D., G.S. Shukla and A.K. Agarwal, 1999. Glutathione depletion and oxidative damage in mitochondria following exposure to cadmium in rat liver and kidney. Toxicol. Lett., 106: 151-157. http://www.ncbi.nlm.nih.gov/pubmed/10403659

66. Martin, H.L., Richert and A. Berthelot, 2003. Magnesium deficiency induces apoptosis in primary cultures of rat hepatocytes. Am. Soc. Nut. Sci. J. Nutr., 133: 2505-2511. http://jn.nutrition.org/cgi/content/full/133/8/2505

67. Barbagallo, M., 1999. Effects of vitamin E and glutathione on glucose metabolism: Role of magnesium. Hypertension, 34: 1002-1006. http://cat.inist.fr/?aModele $=$ afficheN\&cpsidt $=1187$ 447

68. Virginia, M., M.B. Smith, M.J. Brauner and W.P. Majerus, 1971. glutathione biosynthesis in human erythrocytes. J. Clin. Invest. 50: 507-513. http://www.pubmedcentral.nih.gov/articlerender.fc gi?artid=291957 